\title{
Carboxymethylcellulase Produced by Facultative Bacteria from the Hind-gut of the Termite Reticulitermes hesperus
}

\author{
By D. W. THAYER \\ Department of Biological Sciences, Texas Tech University, \\ Lubbock, Texas 79409, U.S.A.
}

(Received 4 January 1978)

\begin{abstract}
Bacillus cereus RW1 and Serratia marcescens Rw3, isolated from the hind-gut of the termite Reticulitermes hesperus, both grew well on mesquite wood and produced moderate amounts of carboxymethylcellulase. Carboxymethylcellulose (CMC) gels were depolymerized rapidly by $B$. cereus RW1 and slowly by $S$. marcescens Rw3. The depolymerization of CMC was $\mathrm{pH}$ and temperature sensitive. Depolymerization of gels by growing cultures of $B$. cereus RW1 and the action of cell-free extracts of B. cereus RW1 on CMC sols were optimum at pH 6.0 and 5.5, respectively. Glucose and cellobiose increased the rate of CMC gel depolymerization. Enzyme synthesis rather than growth was stimulated by the addition of glucose to a culture of RWl growing on a non-cellulosic substrate. Bacillus cereus RW1 produced both cell-free and cell-bound carboxymethylcellulase.
\end{abstract}

\section{INTRODUCTION}

The isolation of bacteria from the hind-gut of the termite Reticulitermes hesperus, their growth on mesquite wood and the depolymerization of carboxymethylcellulose were reported by Thayer (1976). Since wood contains many potential substrates, growth did not necessarily indicate cellulolytic activity. During growth Bacillus cereus RW1 and Serratia marcescens RW3 solubilized 2 to $5 \%$ more mesquite wood than could be achieved by autoclaving, which solubilized $23 \%$. Although B. cereus Rw1 and S. marcescens Rw3 attacked the insoluble components of the wood, they preferred the soluble substrates. Some cellulose hydrolysis and distinct carboxymethylcellulose depolymerization indicated weak cellulolytic activity. Since these organisms were isolated from the hind-gut of the termite and grew on wood, they might contribute to cellulose digestion in the termite. This study characterized the carboxymethylcellulase activity of these organisms.

\section{METHODS}

Organisms. Bacillus cereus RW1 and Serratia marcescens RW3, obtained as described previously from the hind-gut of Reticulitermes hesperus (Thayer, 1976), were maintained on BBL Trypticase Soy Agar (TSA).

Media. The basal medium used to study growth on wood contained ( $\mathrm{g} \mathrm{l}^{-1}$ in distilled water): $\mathrm{NaCl}, 3 \cdot 0$; $\mathrm{KH}_{2} \mathrm{PO}_{4}, 1 \cdot 0 ; \mathrm{K}_{2} \mathrm{HPO}_{4}, 1 \cdot 0 ;\left(\mathrm{NH}_{4}\right)_{2} \mathrm{SO}_{4}, 2 \cdot 0 ; \mathrm{MgSO}_{4}, 0.05 ; \mathrm{CaCl}_{2}, 0.05 ;$ Difco yeast extract, $0.50 ;$ and dormant mesquite wood sawdust, 10.0 ; the $\mathrm{pH}$ was adjusted to 6.5 after autoclaving. To determine the temperatures supporting maximum growth rates, cultures were grown in mineral salts medium containing 5 mm-glucose at $\mathrm{pH} 6.5$ (the medium was sterilized by filtration).

Incubation and inoculation. Cultures were routinely grown at $35^{\circ} \mathrm{C}$ in $100 \mathrm{ml}$ medium in $500 \mathrm{ml}$ baffled Erlenmeyer flasks shaken at $250 \mathrm{rev} . \mathrm{min}^{-1}$ on a gyratory shaker. In some experiments, flasks with an attached $10 \mathrm{~mm}$ diam. cuvette were used; the design of these limited the volume of medium to $80 \mathrm{ml}$. Inocula were $0.1 \mathrm{ml}$ per $100 \mathrm{ml}$ medium.

Measurement of growth. Absorbance measurements were made at $420 \mathrm{~nm}$ in colourless media or at the 
less sensitive $660 \mathrm{~nm}$ in yellow media. Viable cell numbers (colony-forming units) were determined by standard pour-plate count procedures with five replica TSA pour plates per dilution. After maximal development at the appropriate dilution, the colonies on all five Petri plates were counted. Cell protein was measured by the Lowry procedure (Herbert, Phipps \& Strange, 1971).

Carboxymethylcellulase. Carboxymethylcellulase activity was estimated (i) by the release of reducing sugar, (ii) viscometrically, and (iii) by the rate of hydrolysis of carboxymethylcellulose (CMC) gels. The CMC reagent of Miller et al. (1960) was modified to contain $\left(\mathrm{g} \mathrm{l}^{-1}\right): \mathrm{KH}_{2} \mathrm{PO}_{4}, 13 \cdot 61 ; \mathrm{K}_{2} \mathrm{HPO}_{4}, 17 \cdot 42$; sodium carboxymethylcellulose (Sigma no. 8758), 10.0; glucose, 0.10; and thimerosal (ethyl mercurithiosalicylate; Sigma), 0.10; the $\mathrm{pH}$ was adjusted to 6.9. A $4 \mathrm{ml}$ enzyme sample was mixed with $2 \mathrm{ml} \mathrm{CMC} \mathrm{reagent} \mathrm{and}$ incubated at $35^{\circ} \mathrm{C}$ in a sealed $50 \mathrm{ml}$ Erlenmeyer flask in a gyratory water-bath shaker. After incubation, duplicate $2 \mathrm{ml}$ samples were withdrawn, mixed with $3 \mathrm{ml}$ dinitrosalicylic acid reagent (Miller et al., 1960), and held at $100^{\circ} \mathrm{C}$ for $15 \mathrm{~min}$ before determining $A_{640}$. A standard curve was established with glucose.

Carboxymethylcellulose depolymerization was measured viscometrically at $34.9 \pm 0.05^{\circ} \mathrm{C}$ using an Ostwald viscometer with a water efflux time of $22.3 \mathrm{~s}$ at this temperature. One unit of activity was defined as the decrease in the time taken (in seconds) for the efflux of the incubation mixture per minute of incubation (Hulme \& Stranks, 1971). Six efflux times were determined at 5 min intervals; the enzyme dilution was chosen so that the differences between successive readings were $5 \mathrm{~s}$ or less (Hulme, 1971). The standard procedure consisted of mixing $0.1 \mathrm{ml}$ cell-free culture with $2.9 \mathrm{ml} 0.2 \mathrm{M}$-potassium phosphate or $0.2 \mathrm{M}$ sodium acetate buffer and $5 \mathrm{ml} \mathrm{CMC} \mathrm{solution} \mathrm{[containing} 0.5 \mathrm{~g} \mathrm{CMC}$ type 7HF (see below) and $0.01 \mathrm{~g}$ thimerosal per $100 \mathrm{ml}$, and stabilized according to Hulme (1971)]; $5 \mathrm{ml}$ of this mixture was added to the viscometer. The thimerosal did not inhibit enzyme activity. The decreases in efflux time at $34.9^{\circ} \mathrm{C}$ per min of incubation between successive measurements from 5 to 20 min were averaged.

CMC depolymerization was also detected by the liquefaction of gels containing sodium carboxymethylcellulose (Hercules Inc., Wilmington, Delaware, U.S.A.), either type 7HF which has a degree of substitution (DS) of 0.7 and a degree of polymerization (DP) of 3200 , or type $7 \mathrm{LF}$ which has a DS of 0.7 and a DP of 400. The medium contained $\left(\mathrm{g} \mathrm{l}^{-1}\right)$ : CMC, 20,25 or 60 , as indicated in text; phytone (BBL), $10 \cdot 0 ; \mathrm{NaCl}$, 5.0 ; and tap water. The $\mathrm{pH}$ was adjusted to 7.0 and the medium was dispensed in $16 \times 150 \mathrm{~mm}$ test tubes and sterilized. In some experiments, the gel was buffered with $0 \cdot 1 \mathrm{M}$-potassium phosphate to various $\mathrm{pH}$ values, measured after sterilization. Tubes were inoculated with $0.05 \mathrm{ml}$ culture. The depolymerization proceeded from the surface towards the bottom of the gel with zero-order kinetics, reducing the gels to a water-like viscosity. Gel hydrolysis was measured at $2 \mathrm{~d}$ intervals for 16 to $20 \mathrm{~d}$. Hydrolysis rates of CMC media were always compared in the same experiment at different $\mathrm{pH}$ values or temperatures. Rates of hydrolysis were determined by a least squares analysis of all measurements in which less than $100 \%$ of the gel was hydrolysed (Snedecor, 1956).

Location of carboxymethylcellulase activity. Strains were cultivated for $24 \mathrm{~h}$ in BBL Trypticase Soy Broth (TSB) without glucose. The bacteria were harvested by centrifuging at $10000 \mathrm{~g}$ for $30 \mathrm{~min}$ and the supernatant fluid was retained for extracellular enzyme analysis. The bacteria were suspended in $0 \cdot 1 \mathrm{~m}$-potassium phosphate buffer $\mathrm{pH} 7.0$ and a sample of the suspension was disrupted ultrasonically at $20 \mathrm{kHz}$ using a Bronwill Scientific Biosonik Probe.

Catabolite repression of CMC depolymerase. Four identical cultures of $B$. cereus $\mathrm{Rw} 1$ were grown in TSB without glucose; after $8 \mathrm{~h}$, glucose was added to two of the cultures. At various times, $A_{660}$ was monitored; $10 \mathrm{ml}$ samples were removed from each flask and chilled immediately to $4{ }^{\circ} \mathrm{C}$ for protein and enzyme analyses; and $2 \mathrm{ml}$ samples were removed for analysis of whole culture CMC depolymerase activity.

Avicelase. The substrate for the analysis of Avicelase activity $\left(\mathrm{C}_{1}\right.$-cellulase $)$ consisted of $5 \mathrm{~g}$ Avicel $\mathrm{pH} 101$ (FMC Corporation, Newark, Delaware, U.S.A.) in $100 \mathrm{ml} 0.1 \mathrm{M}$-potassium phosphate buffer $\mathrm{pH} 7 \cdot 0$. One $\mathrm{ml}$ substrate was incubated with $1 \mathrm{ml}$ enzyme for $2 \mathrm{~h}$ at $35^{\circ} \mathrm{C}$, and the amount of reducing sugar released was determined as described above. All values were corrected for endogenous reducing sugar.

All experiments were duplicated.

\section{RESULTS}

Carboxymethylcellulase was produced maximally in the late-exponential or stationary phases of growth by strains of $B$. cereus RW1 and $S$. marcescens RW 3 growing on a mesquite wood carbon and energy source (Table 1). Little change occurred in the medium reducing sugar concentration. No cell-free enzymic hydrolysis of Avicel was detected.

An Arrhenius plot of growth rates (Fig. 1a) indicated that the optimum temperature for growth of $B$. cereus RW1 in a glucose/mineral salts medium was between 30 and $40{ }^{\circ} \mathrm{C}$ with an observed maximum at $35^{\circ} \mathrm{C}$. The temperatures at which strain Rw1 caused maximum rates of depolymerization of various CMC type $7 \mathrm{HF}$ gels were: $2 \%$ gel, $40{ }^{\circ} \mathrm{C} ; 2.5 \%$ gel, 
Table 1. Growth and carboxymethylcellulase activities of cultures of strains $\mathrm{RW} 1$ and $\mathrm{RW} 3$ growing on mesquite wood

$\begin{array}{ccccc}\text { Incubation } & \begin{array}{c}10^{-7} \times \\ \text { time } \\ \text { Strain }\end{array} & \begin{array}{c}\text { Colony- } \\ \text { forming } \\ \text { units } \mathrm{ml}^{-1}\end{array} & \begin{array}{c}\text { Reducing } \\ \text { sugar } \\ \left(\mu \mathrm{g} \mathrm{ml}^{-1}\right)\end{array} & \begin{array}{c}\text { Cell-free } \\ \text { carboxymethyl- } \\ \text { cellulase* }\end{array} \\ \text { RW1 } & 0 & 0 \cdot 0036 & 554 & 18 \cdot 7 \\ & 6 & 1 \cdot 23 & 562 & 3 \cdot 8 \\ & 10 & \text { ND } & 500 & 232 \\ & 25 & 12 \cdot 6 & 400 & 154 \\ \text { Rw3 } & 53 & 11 \cdot 4 & 385 & 60 \cdot 0 \\ & 0 & 0 \cdot 161 & 569 & 57 \cdot 7 \\ & 6 & 29 \cdot 8 & 510 & 0 \\ & 10 & 285 & 431 & 20 \cdot 3 \\ & 25 & 369 & 523 & 89 \cdot 9 \\ & 53 & 296 & 431 & 1 \cdot 5\end{array}$

ND, Not determined.

* Activities are expressed as $\mu \mathrm{g}$ reducing sugar produced in $24 \mathrm{~h}$ by $1 \mathrm{ml}$ cell-free culture broth.

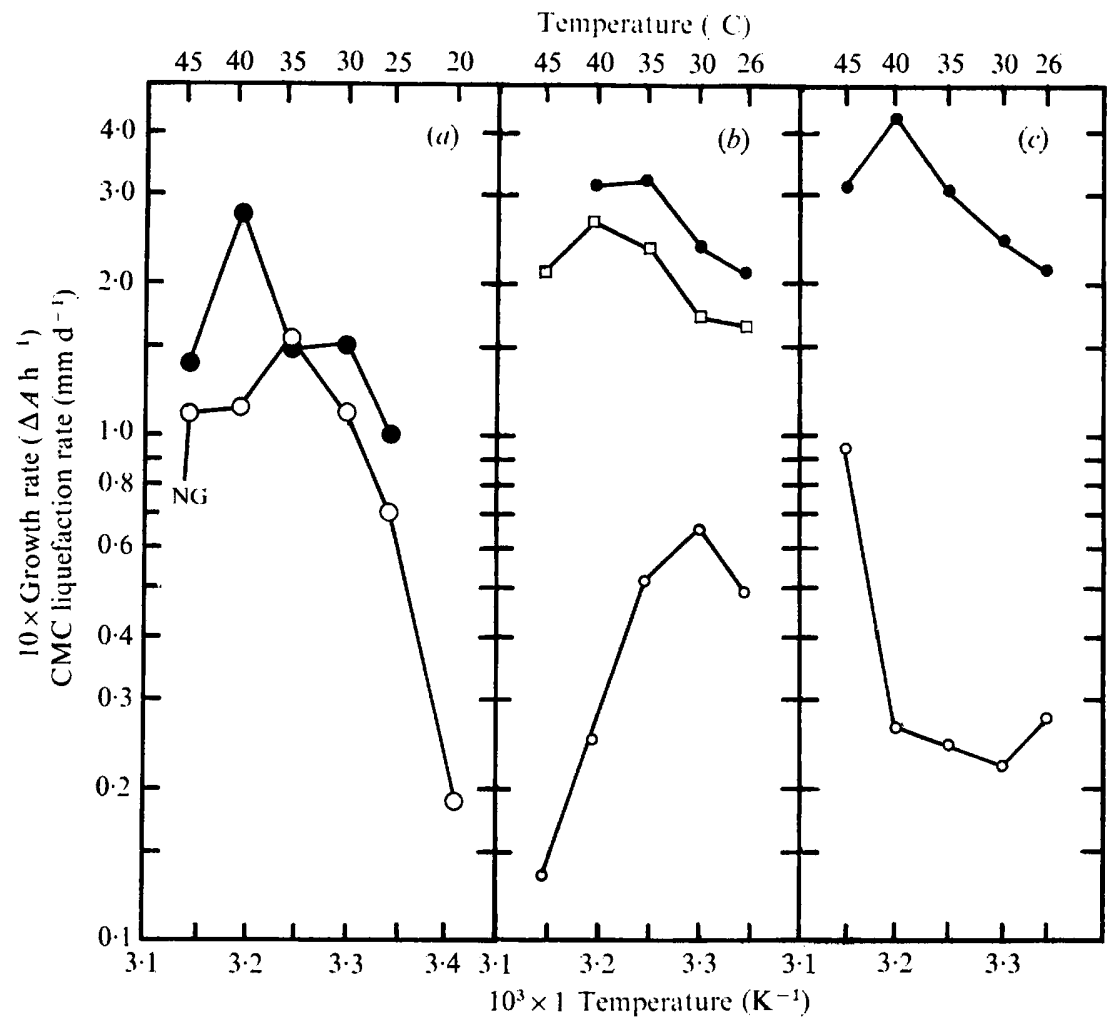

Fig. 1. Arrhenius plots of the rates of liquefaction of CMC type 7HF gels by $B$. cereus Rw1: $(a)$ $2.0 \%$ gel; (b) $\bigcirc, 2.5 \%$ gel; $0,2.5 \%$ gel containing $0.5 \%$ glucose; $\square, 2.5 \%$ gel containing $0.5 \%$ cellobiose; $(c) 0,6.0 \%$ gel; $0,6.0 \%$ gel containing $0.5 \%$ glucose.

Also shown in $(a)$ is an Arrhenius plot of $B$. cereus Rw1 growth rates $(O)$. Duplicate cultures were incubated in a water bath and agitated at $300 \mathrm{rev} . \mathrm{min}^{-1} . A_{420}$ for each culture was recorded at $30 \mathrm{~min}$ intervals for $24 \mathrm{~h}$. Measurements were made at $5{ }^{\circ} \mathrm{C}$ intervals from 20 to $50{ }^{\circ} \mathrm{C}$, but no growth (NG) occurred at $50^{\circ} \mathrm{C}$. 


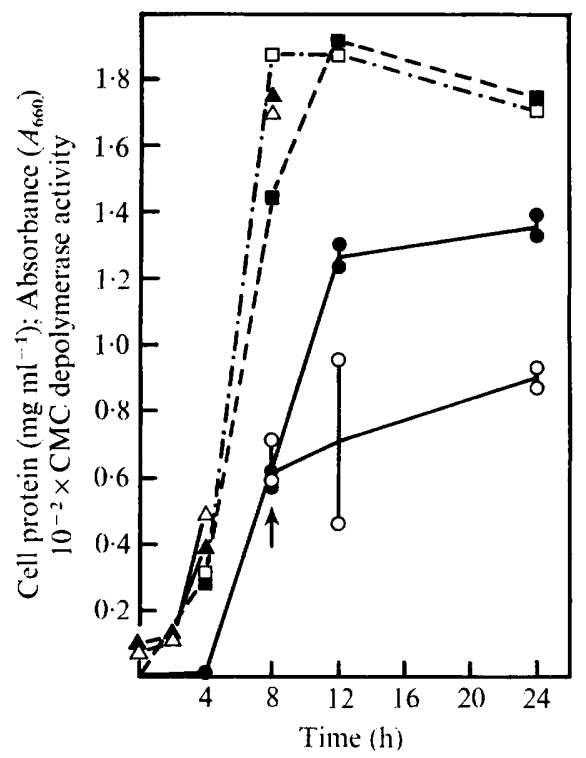

Fig. 2. CMC depolymerase synthesis during batch culture of B. cereus Rw1 in Trypticase Soy Broth: 0 , without glucose (cultures 1 and 2);, $5 \mathrm{ml}$ of a $20 \%(\mathrm{w} / \mathrm{v})$ filter-sterilized glucose solution added before sampling at $8 \mathrm{~h}$, as indicated by the arrow (cultures 3 and 4). [If the enzyme were repressible, CMC depolymerase activity would continue to increase in cultures 1 and 2 after $8 \mathrm{~h}$ but not in cultures 3 and 4.] CMC depolymerase activities are expressed as units (see Methods) per ml culture. Cell protein: $\square$, TSB without glucose; $\mathbf{m}$, TSB with glucose. Culture absorbance at $660 \mathrm{~nm}: \triangle$, TSB without glucose; $\Delta$, TSB with glucose; no further readings were taken once the $A_{660}$ of both cultures exceeded $1 \cdot 7$.

$30{ }^{\circ} \mathrm{C} ; 6.0 \%$ gel, $45{ }^{\circ} \mathrm{C} ; 2.5 \%$ gel containing $0.5 \%$ glucose, $35{ }^{\circ} \mathrm{C} ; 2.5 \%$ gel containing $0.5 \%$ cellobiose, $40{ }^{\circ} \mathrm{C} ; 6.0 \%$ gel containing $0.5 \%$ glucose, $40{ }^{\circ} \mathrm{C}$ (Fig. 1 ). The depolymerization rate increased when either glucose or cellobiose was added to the medium (Figs $1 b, c$ ).

Similar results were obtained with $S$. marcescens Rw3, except that it was less active than B. cereus RWl. The optimum temperature for depolymerization of a $2.0 \%$ CMC type $7 \mathrm{HF}$ gel was $30{ }^{\circ} \mathrm{C}$ with $8 \mathrm{~mm}$ of the gel degraded in $20 \mathrm{~d}$. When $0.5 \%$ glucose was added to the same gel, the optimum shifted to $35^{\circ} \mathrm{C}$ and $47.5 \mathrm{~mm}$ was depolymerized in $15 \mathrm{~d}$. The same $35{ }^{\circ} \mathrm{C}$ optimum was identified for the depolymerization of $6.0 \% \mathrm{CMC}$ type $7 \mathrm{HF}$ gels; $5.5 \mathrm{~mm}$ was depolymerized in $20 \mathrm{~d}$ in the absence of glucose and $13 \mathrm{~mm}$ in its presence. The optimum temperature for the growth of RW 3 in the glucose/mineral salts medium was $40{ }^{\circ} \mathrm{C}$.

Rates of CMC depolymerization by Rw1 or Rw3 were maximum at pH 6.0: in $10 \mathrm{~d}$ at this $\mathrm{pH}$, Rw1 depolymerized $47 \mathrm{~mm}$ of a $2.5 \% \mathrm{CMC}$ (type $7 \mathrm{HF}$ ) gel and $\mathrm{Rw} 3$ depolymerized $17 \mathrm{~mm}$. The rate of CMC gel liquefaction by $B$. cereus Rw1 increased linearly from 0.2 to $4.9 \mathrm{~mm}$ per day as the $\mathrm{pH}$ of the medium was changed from 8.0 to 6.0 ; the rate decreased at $\mathrm{pH} 5 \cdot 0$. The rate of CMC gel liquefaction by $S$. marcescens Rw 3 was $0 \cdot 2 \mathrm{~mm}$ per day at $\mathrm{pH} 6.5$ but $1.2 \mathrm{~mm}$ per day at $\mathrm{pH} 6.0$. A pH of 5.5 was optimum for depolymerization of CMC type 7HF by crude Rw1 cell-free enzyme preparations. There was an $86 \%$ linear increase in activity between $\mathrm{pH} 7.5$ and 5.5 and a $50 \%$ increase between $\mathrm{pH} 4.0$ and 5.5 in phosphate buffers. Uninoculated controls were unaltered at the end of the experiment.

When glucose was added to a growing culture in TSB, CMC depolymerase activity increased approximately $1 \cdot 8$-fold. No such increase in absorbance or cell protein was observed (Fig. 2). Addition of glucose to crude cell-free preparations did not increase CMC depolymerase activity.

Carboxymethylcellulase activities in cell-free, whole-cell and broken-cell preparations are 
Table 2. Carboxymethylcellulase activities in cell-free culture broth, whole-cell suspensions and broken-cell suspensions of strains $\mathrm{RW} 1$ and $\mathrm{RW} 3$

\begin{tabular}{|c|c|c|c|c|c|}
\hline \multirow[b]{2}{*}{ Strain } & \multirow[b]{2}{*}{$\begin{array}{c}\text { Cell } \\
\text { protein } \\
\left(\mu \mathrm{g} \mathrm{ml}^{-1}\right)\end{array}$} & \multicolumn{3}{|c|}{ Carboxymethylcellulase* } & \multirow[b]{2}{*}{$\begin{array}{c}\begin{array}{c}\text { Ratio } \\
\text { Cell-free }\end{array} \\
\text { Whole-cell }\end{array}$} \\
\hline & & $\begin{array}{l}\text { Cell-free } \\
\text { culture } \\
\text { broth }\end{array}$ & $\begin{array}{l}\text { Whole-cell } \\
\text { suspension }\end{array}$ & $\begin{array}{l}\text { Broken-cell } \\
\text { suspension }\end{array}$ & \\
\hline RW1 & 600 & $71 \cdot 0$ & $11 \cdot 1$ & $51 \cdot 0$ & $6 \cdot 4$ \\
\hline Rw3 & 400 & 0 & 0 & $66 \cdot 5$ & - \\
\hline
\end{tabular}

* Activities are expressed as $\mu$ mol glucose produced in $24 \mathrm{~h}$ per $\mathrm{mg}$ cell protein.

shown in Table 2. Bacillus cereus Rw1 had both cell-free and cell-bound activities. Serratia marcescens RW 3 had only cell-bound activity that was expressed only after the cells had been disrupted ultrasonically. Neither culture produced demonstrable Avicelase activity.

\section{DISCUSSION}

Bacillus cereus RW1 and S. marcescens RW3 grew well on mesquite wood and produced carboxymethylcellulase activity which was related to the age and cell density of the cultures. It is not known what role carboxymethylcellulase may have in the actual hydrolysis of wood especially in the hind-gut of a termite.

The use of CMC gels for detection of $\mathrm{pH}$ and temperature optima for depolymerization proved valuable. The optimum temperature for growth corresponded well with that for the hydrolysis of CMC gels. The gel technique gave similar results to enzymic analysis and thus was valuable for surveying the CMC depolymerization activities of bacterial cultures. Its relative simplicity makes the gel technique ideal for comparing several cultures.

Cellobiose is a competitive inhibitor of the cellulase activity of Trichoderma (Halliwell, Griffin \& Vincent, 1972). The unexpected increase in CMC depolymerization rates in the presence of glucose or cellobiose made it imperative to assay the effects of adding carbohydrates under conditions where growth effects could be separated from enzymic activity. The addition of glucose to cultures of B. cereus Rw1 in TSB increased production of CMC depolymerase without increasing bacterial protein. The synthesis and activity of the CMC depolymerase in B. cereus RWl does not appear to be subject to the usual end-product regulation. Instead, its synthesis was enhanced by the sugar, since adding glucose before sampling at $8 \mathrm{~h}$ caused neither immediate nor delayed increases in enzymic activity. This was confirmed in a separate study.

In Myrothecium verrucaria, Hulme \& Stranks (1971) observed that cellulase was produced when glucose was used as a carbon source in rate-limiting amounts, and concluded that cellulase in $M$. verrucaria was constitutive and that its production was partially controlled by catabolite repression. Since carboxymethylcellulase and CMC depolymerase were produced by,RW1 and RW3 in the absence of any cellulosic materials, the enzyme(s) must be constitutive. The increased synthesis of CMC depolymerase by Rw1 in the presence of glucose indicated possible enzyme induction by this substrate. Suzuki, Yamane \& Nisizawa (1969) noted the formation of both cell-bound and extracellular cellulase by Pseudomonas fluorescens var. cellulosa when glucose, cellobiose, sophorose or cellulose was the carbon source. Sophorose and cellulose stimulated the synthesis of extracellular cellulase. Sophorose also induced cellulase synthesis in Trichoderma viride (Mandels, Parrish \& Reese, 1962) and P. fluorescens var. cellulosa (Yamane et al., 1970). Mandels et al. (1962) demonstrated that sophorose was a contaminant of some commercial preparations of glucose. The reagents used in this study were of the highest commercial purity but may have contained some sophorose. Mandels \& Reese (1960) reported that high concentrations $(0.5$ to $1.0 \%)$ of cellobiose or other rapidly 
metabolized carbon sources strongly repressed cellulase formation by $T$. viride, and addition of glucose or cellobiose to a culture producing cellulase (carboxymethylcellulase) inactivated the enzyme already formed. The conditions used in this study were predicted to inactivate or to stop synthesis of cellulase. The regulation of cellulase synthesis in both $B$. cereus Rw1 and $S$. marcescens RW3 appears to differ from the fungal and bacterial systems described above and should be investigated further.

\section{REFERENCES}

Halliwell, G., Griffin, M. \& Vincent, R. (1972). The role of component $C_{1}$ in cellulolytic systems. Biochemical Journal 127, 43P.

Herbert, C., Phipps, P. J. \& Strange, R. E. (1971). Chemical analysis of microbial cells. Methods in Microbiology 5B, 209-344.

Hulme, M. A. (1971). Viscometric determination of carboxymethylcellulase in standard international units. Archives of Biochemistry and Biophysics 147, 49-54.

Hulme, M. A. \& Stranks, D. W. (1971). Regulation of cellulase production by Myrothecium verrucaria grown on non-cellulosic substrates. Journal of General Microbiology 69, 145-155.

MANDELS, M. \& ReESE, E. T. (1960). Induction of cellulase in fungi by cellobiose. Journal of Bacterio$\log y$ 79, 816-826.

Mandels, M., Parrish, F. W. \& Reese, E. T. (1962). Sophorose as an inducer of cellulase in Trichoderma viride. Journal of Bacteriology 83, 400-408.
Miller, G. L., Blum, R., Glennon, W. E. \& Burton, A. L. (1960). Measurement of carboxymethylcellulase activity. Analytical Biochemistry 12, 127-132.

SNEDECOR, G. W. (1956). Statistical Methods. Ames: Iowa State University Press.

Suzuki, H., Yamane, K. \& Nisizawa, K. (1969). Extracellular and cell-bound cellulase components of bacteria. In Cellulases and their Applications, Advances in Chemistry Series 95, pp. 60-82. Edited by R. F. Gould. Washington: American Chemical Society.

THAYER, D. W. (1976). Facultative wood-digesting bacteria from the hind-gut of the termite Reticulitermes hesperus. Journal of General Microbiology 95, 287-296.

Yamane, K., Suzuki, H., Hirotani, M., Ozawa, H. \& Nisizawa, K. (1970). Effect of nature and supply of carbon sources on cellulase formation in Pseudomonas fluorescens var. cellulosa. Journal of Biochemistry 67, 9-18. 